\title{
酸 New Disease Reports \\ New isolates of Citrus tristeza virus naturally occurring in old lemon and mandarin trees in Greece
}

\author{
I. Malandraki ${ }^{1}$, E. Marouli ${ }^{2}$ and C. Varveri ${ }^{1 *}$ \\ ${ }^{1}$ Benaki Phytopathological Institute, 8 S. Delta Str. 14561 Kifissia, Athens, Greece ; ${ }^{2}$ Directorate of Agriculture, Prefecture \\ Piraeus, 18531 Piraeus, Greece \\ *E-mail: c.varveri@bpi.gr
}

Received: 10 Aug 2010. Published: 12 Jan 2011. Keywords: phylogenetic analysis, CTV, cp gene, p20 gene

Citrus tristeza virus (CTV) has quarantine status in Greece. The virus was first reported in 2000 in non-certified sweet orange trees grafted on CTV-tolerant Carrizo citrange originating from Spain (Dimou et al., 2002). High homology of these isolates was then found with the Spanish mild T385 isolate (bio-group 1, Garnsey et al., 2005) from sweet orange grafted on sour orange rootstock, sharing $100 \%$ nucleotide sequence identity for the p20 gene (Varveri, 2006). In 2009, surveys were conducted in the area of Poros (Trizinia, Prefecture of Pireaus), where about 20,000 citrus trees grow, mainly lemon. (This was an area previously devoted to citrus cultivation for more than 100 years but now consisting virtually of a wood protected only for its beauty and historical importance). A total of 285 citrus trees, $87 \%$ of which were lemon, were tested by ELISA (Enzyme-Linked Immunosorbent Assay) in a programme lasting until September 2010. Six trees (four lemons and two mandarins) were found positive. None of the above mentioned trees showed any symptoms.

All ELISA positive samples were confirmed with reverse transcription-polymerase chain reaction (RT-PCR). Two sets of primers targeting the p20 protein (PM48 CGAGCTTACTTTAGTGTTA and PM49 TAATGTCAAACTGACCGC) (Sambade et al., 2002) and the coat protein (cp) genes (CTV1 ATGGACGACGAAACAAAGAA and CTV10 ATCAACGTGTGTTGAATTTCC) (Nolasco et al., 2002) were used. PCR products were purified using the QIAquick Gel Extraction Kit (QIAGEN $\mathrm{GmbH}$, Hilden, Germany) and subjected to bidirectional direct sequencing (Macrogen, Inc., Seoul, Korea). Partial sequences of the p20 (483 bp) and cp (617-632 bp) genes of two lemon (L192GR, L594GR) and one mandarin (M8GR) CTV isolates were obtained and deposited in GenBank with the Accession Numbers recorded in Table 1. Sequence comparisons of the cp gene nucleotide sequences (HQ270181, HQ270182, and HQ270183) revealed a 99\% identity with CTV isolates from Brazil (I141-62, I141-59), Cyprus (CY96-18, CY93-10, CY89-507) and Portugal (28C) (Table 1), belonging to the $3 \mathrm{~b}$ genotype group of CTV isolates (Nolasco et al., 2009). Nucleotide sequences of the p20 gene (HQ270180, HQ270185, and HQ270186) showed a 99\% identity with a seedling yellows (SY) isolate from Brazil (Galego 50) belonging to bio-group 3 of CTV isolates (Garnsey et al., 2005). Further phylogenetic analysis involving standard, fully sequenced and well characterized natural CTV isolates showed that the newly recovered isolates share a common ancestor with the VT seedling yellows (bio-group 4) isolate from Israel, which reveals a totally different topology in the obtained phylogenetic trees from the mild CTV isolates recovered in 2000-2001 in the country (data not shown). The immunological reaction with the MCA13 monoclonal antibody confirmed the occurrence of a virus strain more virulent than the one thus far recorded in orange groves in Greece. Natural isolation of the "lemonwood" in Poros from hills and the sea has apparently hindered the spread of these isolates in sweet orange trees further on in the same region, which however represents a threat for the local citrus industry. Surveys are being continued intensively in Poros aiming at eradicating CTV. Our findings confirm previous conclusions on the diversity of CTV isolates in the Mediterranean basin reflecting the worldwide virus diversity.

\section{References}

Dimou D, Drossopoulou J, Moschos E, Varveri C, Bem F, 2002. First report of Citrus tristeza virus in Greece. Plant Disease 86, 329. [doi:10.1094/PDIS.2002.86.3.329B]

Garnsey SM, Civerolo EL, Gumpf DJ, Paul C, Hilf ME, Lee RF, Brlansky RH, Yokomi RK, Hartung JS, 2005. Biological characterisation of an international collection of Citrus tristeza virus (CTV) isolates. In: Proceedings 16th Conference IOCV, 75-93. IOCV, Riverside, CA, USA.

Nolasco G, Santos C, Silva G, Fonseca F, 2009. Development of an asymmetric PCR-ELISA typing method for citrus tristeza virus based on the coat protein gene. Journal of Virological Methods 155, 97-108. [doi:10.1016/j.jviromet.2008.09.030]

Nolasco G, Sequeira Z, Soares C, Mansinho A, Bailey AM, Niblett CL, 2002. Asymmetric PCR ELISA: increased sensitivity and reduced costs for the detection of plant viruses. European Journal of Plant Pathology 108, 293-298. [doi:10.1023/A:1015649429160]

Sambade A, Rubio L, Garnsey SM, Costa N, Müller GW, Peyrou M, Guerri J, Moreno P, 2002. Comparison of viral RNA populations of pathogenically distinct isolates of Citrus tristeza virus: application to monitoring cross-protection. Plant Pathology 51, 257-265.

[doi:10.1046/j.1365-3059.2002.00720.x]

Varveri C, 2006. Molecular detection and characterization of Citrus tristeza virus in Greece. Phytopathologia Mediterranea 45, 68 (Abstract).

\begin{tabular}{|c|c|c|c|}
\hline Isolate & Origin & Gene & $\begin{array}{l}\text { GenBank } \\
\text { Accession No }\end{array}$ \\
\hline L192GR & Greece (Poros) & $\begin{array}{l}\mathrm{p} 20 \\
\mathrm{cp}\end{array}$ & $\begin{array}{l}\text { HQ270185 } \\
\text { HQ270182 }\end{array}$ \\
\hline L594GR & Greece (Poros) & $\begin{array}{l}\mathrm{p} 20 \\
\mathrm{cp}\end{array}$ & $\begin{array}{l}\text { HQ270180 } \\
\text { HQ270181 }\end{array}$ \\
\hline M8GR & Greece (Poros) & $\mathrm{p} 20$ & HQ270186 \\
\hline II $141-62$ & Brazil & $c p$ & EU579359 \\
\hline I141-59 & Brazil & cp & EU579358 \\
\hline CY96-18 & Cyprus & cp & EF491677 \\
\hline CY93-10 & Cyprus & cp & EF491676 \\
\hline CY89-507 & Cyprus & cp & EF491675 \\
\hline $28 \mathrm{C}$ & Portugal & cp & AF184118 \\
\hline $\begin{array}{l}\text { Galego } 50 \\
\text { VT }\end{array}$ & $\begin{array}{l}\text { Brazil } \\
\text { Irsael }\end{array}$ & p20 & $\begin{array}{l}\text { FM955991 } \\
\text { US6902 }\end{array}$ \\
\hline
\end{tabular}

To cite this report: Malandraki I, Marouli E, Varveri C, 2011. New isolates of Citrus tristeza virus naturally occurring in old lemon and mandarin trees in Greece. New Disease Reports 23, 2. [doi:10.5197/j.2044-0588.2011.023.002] 